\title{
Eosinophilic Myelocyte Count
}

National Cancer Institute

\section{Source}

National Cancer Institute. Eosinophilic Myelocyte Count. NCI Thesaurus. Code C84821.

The determination of the number of eosinophilic myelocytes in a blood sample. 